\title{
Study on Understanding about Food Hygiene among Street Food Vendors in Lucknow, Uttar Pradesh
}

\section{Rajendra Kumar}

Amity Business School, Amity University Uttar Pradesh, Lucknow Campus, Gomtinagar Extension (Near Malhaur Railway Station), Lucknow- 226028, U.P., India. E-mail: Rkumar1@1ko.amity.edu, vision.agri@ rediffmail.com

\begin{abstract}
Street foods are encompassing meals, drinks, and snacks and exposed to climate and temperature, unsafe water supplies, unsanitary conditions. These foods also raise concern with respect to their potential for serious food poisoning outbreaks. A number of factors are taken into consideration when deciding on food hygiene of street food products, such Personal cleanliness, surrounding cleanliness and Utensils cleanliness. In order of these determinants, this study was conducted in urban area of Lucknow, Uttar Pradesh to know the street food understanding about food hygiene. The results indicate that the maximum street vendors were male, belonged to age group of 26-45 years and had high school, graduate education with their understanding of food hygiene were not found sufficient to maintain food hygiene during preparing, cooking and serving foods to consumers. Therefore, from the practical standpoint, it is need to create awareness in order to increase awareness about food hygiene among street food consumers.
\end{abstract}

Key words: Food hygiene, understanding, personal cleanliness, street foods, utensils and surrounding cleanliness.

Paper cited: Kumar, R. (2016). Study on Understanding about Food Hygiene among Street Food Vendors in Lucknow, Uttar Pradesh. South Asian Journal of Food Technology and Environment, 2(3\&4): 452-457.

\section{Introduction}

The street food industry plays an important role in cities and towns of many developing countries both economically and in meeting food demands of city dwellers (CressWilliams, 2001). Its expansion is linked with urbanization and the need of urban population for both employment and food. The street food vendors of Lucknow operate from busy spots all over the city, lining streets, markets, and traffic junctions. Most street food vendors operate their food stands alone and generate sufficient income to provide for their daily lives.

The street foods are quick snacks, lunch or ready-to-eat foods and beverages commonly sold at display counters, refreshment parlors or at vending stalls by street food vendors and hawkers who are either stationary or ambulatory (Kumar and Gupta, 2016). The Food and Agricultural Organization (FAO) had defined street foods as "ready to-eat foods and beverages prepared and sold by vendors and hawkers in streets and other similar public places" (FAO, 2010).

The street food is a public health concern, since safe food hygiene can be difficult to practice at street level in settings where resources are scarce and surroundings are of low environmental and sanitary standards. Multiple lines of evidence reveal that foods exposed for sale on the roadsides may become contaminated either by spoilage or pathogenic microorganisms (Bryan, et al., 1992; Ashenafi, 1995; WHO, 1984). FAO (1997) further stipulates that 


\section{Rajendra Kumar}

street foods raise concern with respect to their potential for serious food poisoning outbreaks.

The street foods in Lucknow are found in all areas of city and these street foods are exposed to climate and temperature, unsafe water supplies, unsanitary conditions. However, very little is known about how street food vendors themselves understand about food hygiene in Lucknow. Keeping this fact in view, in the present study, therefore an attempt has been made to explore understanding about health-related aspects of hygiene amongst street food vendors Lucknow:

(i) Personal cleanliness,

(ii) Surrounding cleanliness,

(iii) Utensils cleanliness

(iv) All of Above.

Street foods are ready -to-eat foods and beverages prepared and/or sold by vendors, especially on streets and other public places (Muleta and Ashenafi, 2001).

In order to process and handle food safety, the foremost and most fundamental consideration must be food hygiene. "Food hygiene" refers to all conditions and measures necessary for the safety and suitability of food at all stages of the food supply chain.

Perception or understanding is the process by which physical sensations are selected, organized and interpret. The eventual interpretation of a stimulus allows it to be assigned meaning. Many stimuli compete for vendor attention and the majority are not noticed or comprehended. Every food hygiene communication message contains a relationship between the product, the sign and the interpretation of meaning. Beyond perception, interpretation of the signs and previous experience with goods are decisive factors in getting meaning.

The microbial quality of street foods was equivalent to, if not better, than that of foods bought from hotels and restaurants,
Atkinson (1992), Bapat (1992), Chakravarty (1994) and Tinker (1987). Evidently, street vended foods have shown epidemiological links with illness (El-Sherbeeny et al., 1985; Saddik et al., 1985; Abdussan and Kafertein, 1993).

The Street food is a public health concern, since safe food hygiene can be difficult to practice at street level in settings where resources are scarce and surroundings are of low environmental and sanitary standards. Diarrheal diseases due to contaminated and unhygienic food are among the leading causes of illness and deaths in low-income countries and several outbreaks of disease have been attributed to the consumption of street food.

\section{Materials and Methods}

The study titled on "understanding of food hygiene among food vendors in urban area of Lucknow, Uttar Pradesh" was carried out during November 20 to 25, 2016. Sample used for the investigation were selected from Gomati Nagar, Indira Nagar, Aliganj, Mahanagar, Alambagh and Chauk in Lucknow. Thus total 30 samples of street vendors i.e. 05 venders each from the 06 locations were selected randomly and were studied separately using survey method for recording data on demographic and food hygiene issues as:

(a) Demographic Features: (i) Age, Gender, (iii) Educational Level.

(b) Food Hygiene: (i) Personal cleanliness, (ii) Surrounding cleanliness, (iii) Utensils cleanliness (iv) All of Above.

Research Design: In this study qualitative research approach was adopted.

Data Collection Tools: Primary data were collected by conducting a face-to-face interview using a standardized and structured questionnaire. Simultaneously secondary data were collected from newspapers, research journal, magazines, internet, libraries, etc. 
Data analysis: Collected data arranged and tabulated in Excel and imported into SPSS version 12.0 (2003) for windows for analysis, including frequencies and per cent, for all variables.

\section{Results and discussion}

The findings of "study on understanding of food hygiene among vendors in urban areas of Lucknow, Uttar Pradesh" have been arranged and analyzed.

\section{(a) Demographic Features}

The observations of demographic features of street vendors were recorded and are presented in Table 1:

Table-1: Demographic Features of street vendors

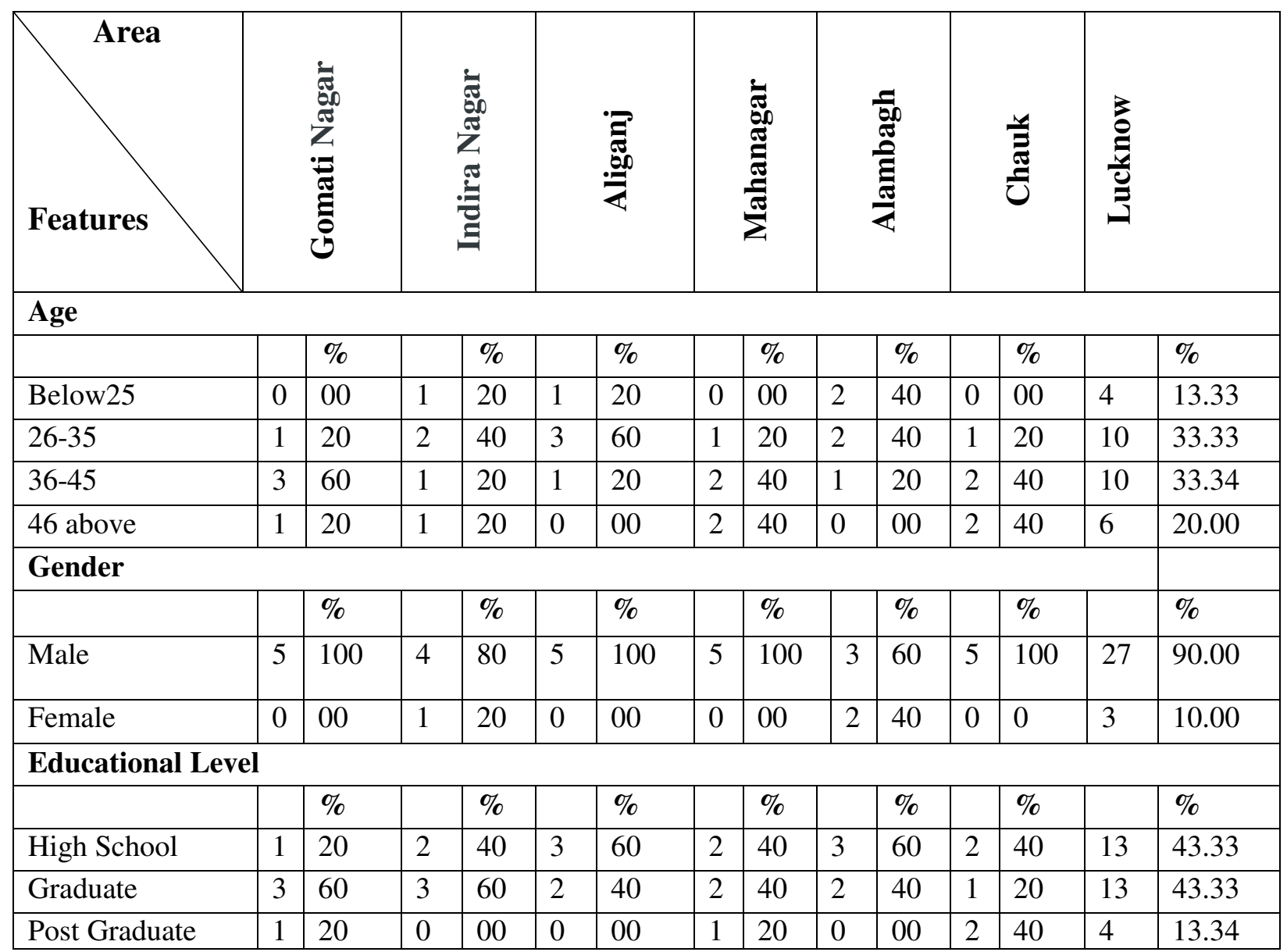

From data given, it is evident from the above table that there was not much variability in demographic features of street vendors of different location was found. Analyses of demographic features are as follows:-

Age: The age of street vendors in Gomati Nagar were found between 26-35 years (20 per cent), $36-45$ years (60 per cent) and above 46 years South Asian J. Food Technol. Environ., 2(3\&4): 452-457 (2016) were 20 per cent. In Indira Nagar vendors having age between $26-35$ years (40 per cent) and remaining 20per cent vendors belonged to each below 25 years, 36 to 45 years and above 46 years group. In Aliganj 60 per cent vendors belonged to age group $26-35$ years and remaining 20 per cent vendors belonged to each below 25 years and 36-45 years group. In 
Mahanagar area 40 per cent vendors belonged to each group of 36-45 years and above 46 years followed by 20 per cent of 26-35 years. 40 per cent vendors in Alambagh area were belonging to each age group below 25 years and $26-35$ years followed by 20 per cent to $36-45$ years. In Chauk area 40 per cent vendor were belonging to each age group of 36-45 years and above 46 years followed by 20 per cent 26-35 years (Table 1).

The street vendors in Lucknow comprised of age group of 36- 45 years (33.34 per cent) and 26-35 years( 33.33 per cent), followed by 20 per cent above 46 years and 13.33 per cent vendors below 25 years.(Table 1). Gender: The street vendors in all location are dominated by male vendors. In Gomati Nagar, Aliganj, Mahanagar and Chauk vendor shops are run by male vendors, where as in Indira Nagar and Alambagh female vendors are selling food through street shops (Table 1).

In Lucknow urban area the street vendors are dominated by male vendors (90 per cent) and only 10 percent by women vendors (Table 1).

Educational Level: The educational level varied from high school to post graduate. Street vendors were having education up to high school in Alambagh and Aliganj (60 per cent) followed by Indira Nagar, Mahanagar and Chauk (40 per cent). Similarly in Gomati Nagar and Indira Nagar 60 percent vendors having graduate education while 40 percent vendors were post graduate in Chauk area in Lucknow (Table 1).

In Lucknow the educational level varied from high school to post graduate. Street vendors were having education up to high school (44 per cent) followed graduate (43 per cent) where as 13 per cent vendors were having post graduate education.

\section{(b) Food Hygiene}

Data on understanding issues about food hygiene among street vendors of selected areas of Lucknow were analyzed and observation recorded are presented in Table 2.

Table-2: Food hygiene Perception of street vendors

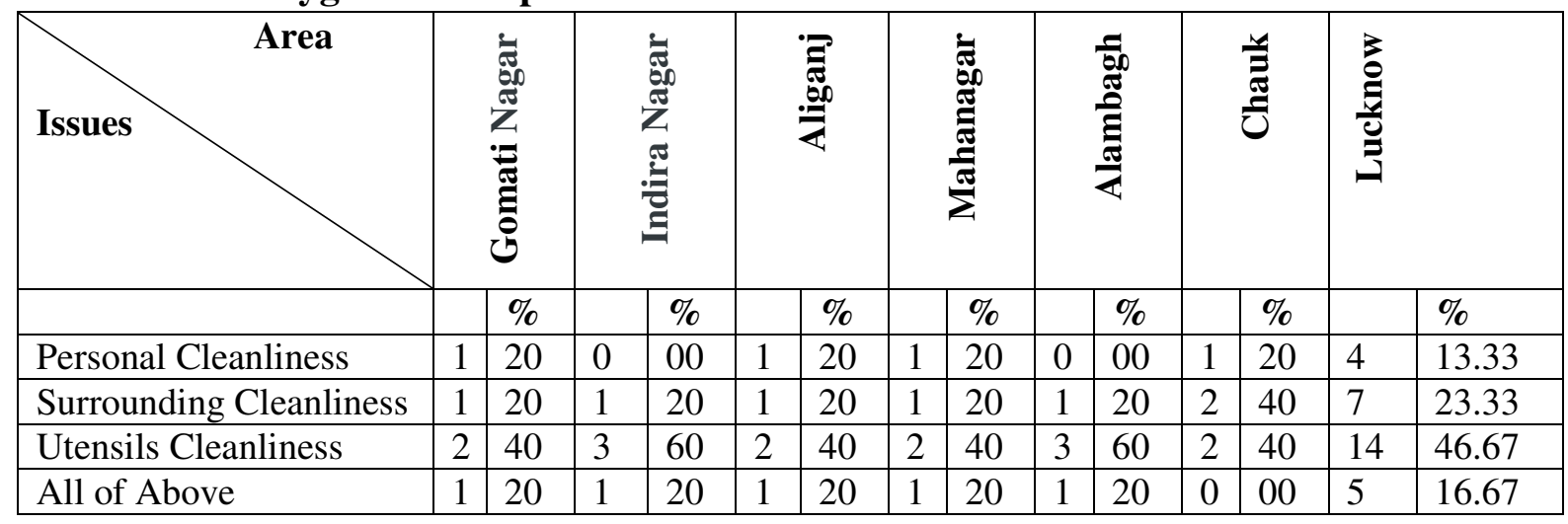

Personal Cleanliness: It was observed that in Gomati Nagar, Mahanagar, Aliganj, and Chauk street vendors are considering equally (20 per cent) while in Indira Nagar and Alambagh area they were not having any understanding about these issues.
Surrounding Cleanliness: 40 per cent Street vendors in Chauk area were having understanding about surrounding cleanliness was an issue of food hygiene followed by 20 per cent vendors in Gomti Nagar, Indira Nagar, Mahanagar, Aliganj, Alambagh. 
Utensils Cleanliness: 60 per cent street vendors in Indira Nagar and Alambagh area were aware about utensils cleanliness is an issue of food hygiene followed by 40 per cent vendors in Gomti Nagar, Mahanagar, Aliganj and Chauk.

The street vendors of selected areas were having understanding about Personal, Surrounding and Utensils Cleanliness are issues of food hygiene by 20 per cent vendors in Gomti Nagar, Indira Nagar, Mahanagar, Aliganj, Alambagh where as Chauk area's vendors was neglecting issues of food hygiene (Table 2).

In Lucknow 46.67 per cent street vendors were aware about that Utensils Cleanliness is issue of food hygiene followed by surrounding cleanliness (23.33 per cent), personal cleanliness (13.33 per cent) and about all identified issues of food hygiene only 16.67 per cent street vendors have understanding (Table 2).

\section{Conclusion}

The maximum street vendors were male, belonged to age group of 26-45 years and had high school, graduate education with their understanding of food hygiene were not found sufficient to maintain food hygiene during preparing, cooking and serving foods to consumers.

\section{Limitations}

This was a limited period study. Therefore, 06 days were very short time to cover all area of Lucknow.

\section{Recommendations}

It is obvious from the study that in Lucknow Street food vendors are not much aware about food hygiene and also not consider food hygiene issues at their street outlets (Kumar, 2016). Therefore, it is need to create awareness about food hygiene to prepare safe food.

\section{References}

1. Abdussalam, M. and Kaferstein, F.K. (1993). Safety of street foods. World Health Forum, 14:191-194.

2. Ashenafi, M. (1995). Bacteriological profile and holding temperature of readyto-serve food items in an open market in Awassa, Ethiopia. Trop. Geogr. Med, 47: 1-4.

3. Atkinson, S.J. (1992). Food for the Cities: Urban Nutrition Policy in Developing Countries. London: London School of Hygiene and Tropical Medicine, Dept. Public Health and Policy.

4. Bapat, M. (1992). Street Food Vending in Pune. India: Center of Studies in Social Sciences.

5. Bryan, F.L., Teufel, P., Riaz, S., Roohi, S., Qadar, F and Malik, Z. (1992). Hazards and critical control points of vending operations at a railway station and a bus station in Pakistan. Journal of Food Protection, 55: 334-541.

6. Chakravarty, I. (1994). Ensuring the Safety of Street Foods in Calcutta. Proceedings of the Second Asian Conference on Food Safety. Bangkok, Thailand, Sep. 19-23,1994.

7. Cress-Williams, L. (2001). Food Micro Enterprises for Food Security in an Urban Slum Community in East London: Development of an Awareness-Creating Programme. Unpublished Dissertation. Stellenbosch University.

8. El-Sherbeeny, M.R., Saddik, M.F. and Bryan, F.Z. (1985). Microbiological profiles of food served by street vendors in Egypt. International Journal of Food Microbiology, 2: 355-362.

9. FAO (2010). Street food: small entrepreneurs, big business. http://www.Fao/NEWS/1997/97/970408e.htm.(assessed 28 April 2010). 
10. Kumar, R. (2016). Study on perception of street food venders about food safety in Lucknow. South Asian Journal of Food Technology and Environment, 1(2): 136139.

11. Kumar, R. and Gupta, R.P. (2016). Study on understanding about food hygiene among street food consumers in Lucknow (Uttar Pradesh). VSRD International Journal of Technical \& Non-Technical Research, VII (V): 81-88.

12. Muleta, D. and Ashenafi, M. (2001). Salmonella, Shigella and Growth potential of other food-bourne pathogens in Ethiopian street vended foods. East
African Medical Journal, 78 (11): 576580.

13. Saddik M.F., El-Sherbeeny, M.R., Mousa, B.M., El-Akkad, A. and Bryan, F.L.(1985). Microbiological profile and storage temperatures of Egyptian fish and other sea foods. Journal of Food Protection, 48:403-406.

14. SPSS, Version 12.0 (2003). SPSS Web site at http://www.spss.com/worldwide

15. Tinker, I. (1987). Street Foods. Current Sociology, 35:1-110

16. WHO. (1984), the role of Food Safety in Health and Development: Report of a joint FAO/WHO Expert Committee on Food Safety. Technical Report Series, No. 705.

\section{Received: June 2016, Revised: August 2016, Accepted: September 2016}

